Удк $338.47,338.49$

O. В. Пантась,

здобувачка магістратури за спечіальністю "Публічне управління та адміністрування"

кафедри управління охороною здоров' я та публічного адміністрування

Начіонального університету охорони здоров' я України імені П. А. Шупика

ORCID ID: 0000-0002-6504-9222

В. П. Писаренко,

д. держ. упр., професор кафедри управління охороною здоров' я та публічного адміністрування, Начіональний університет охорони здоров' я України імені П. А. Шупика

ORCID ID: 0000-0003-4789-5756

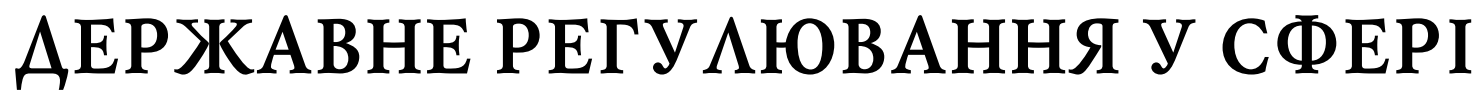 TРАНСПОРТУ
}

\author{
O. Pantas, \\ Master's student of the Department of Healthcare Management and Public Administration, \\ Shupyk National Healthcare University of Ukraine, Kyiv, Ukraine \\ V. Pysarenko, \\ Doctor of Sciences in Public Administration, Professor of the Department of Healthcare Management and Public \\ Administration, Shupyk National Healthcare University of Ukraine, Kyiv, Ukraine
}

\section{STATE REGULATION IN THE FIELD OF TRANSPORT}

\begin{abstract}
Статтю присвячено дослідженню державного регулювання у сфері транспортуУкраїни. Державне регулювання у сфері транспорту - це процес створення комплексу умов для формування адекватних соціально-економічних відносин для забезпечення цілеспрямованого розвитку транспортної системи, яка має високу соціальну значущість. Створення таких умов досягається через застосування різних форм і методів державного регулювання у сфері транспорту. у статті визначено сутність державного регулювання, проведено аналіз наукової літератури, що визначає основні аспекти державного регулювання у сфері транспорту. Стаття містить уточнення поняття транспортної сфери та транспортної інфраструктури та визначає основні суб'єкти, які формують їі. В ході дослідження систематизовано інформацію про державне регулювання транспортної галузі, виділено політичні, економічні, інформаційні та екологічні аспекти державного регулювання.

За останні 20 років більшість країн світу намагаються удосконалювати свою транспортну інфраструктуру шляхом удосконалення рівня державного регулювання, яке дозволяє не тільки організувати, але й вести постійний і дієвий контроль за діяльністю транспортного сектору. Що стосується України, то останніми роками практично у всьому транспортному комплексі відчувається погіршення ситуації у всіх галузях транспорту, окрім авіатранспорту. Це підтверджує актуальність дослідження державного регулювання у сфері транспорту, що дозволить знайти напрями вирішення ситуації, що склалася.

Визначено основні органи, які здійснюють державне регулювання у сфері автотранспорту, для цього запропоновану трирівневу ієрархічну структуру, яка формується на національному, регіональному та місцевому рівні. Визначені основні завдання Міністерства інфраструктури України та відображено його роль у діяльності транспортної галузі. Розглянуто сфери впливу кожного із органів регулювання на різні види транспорту.
\end{abstract}


Окрім систематизації інформації про інституційне регулювання транспортної сфери, здійснено аналіз нормативно-правової бази у цій області. Визначено основні проблемні моменти державного регулювання транспортної сфери і вперше запропоновано заходи, які дозволять вирішити зазначені питання відповідно до сучасного стану галузі.

This article is devoted to the study of state regulation in the field of transport in Ukraine. State regulation in the field of transport is a process of creating a set of conditions for the formation of adequate socio-economic relations to ensure the purposeful development of the transport system, which has a high social significance. The creation of such conditions is achieved through the use of various forms and methods of state regulation in the field of transport. The article defines the essence of state regulation, analyzes the scientific literature, which determines the main aspects of state regulation in the field of transport. The article clarifies the concept of transport and transport infrastructure and identifies the main actors that form it. The study systematizes information on state regulation of the transport sector, highlights the political, economic, informational and environmental aspects of state regulation.

Over the past 20 years, most countries around the world have been trying to improve their transport infrastructure by improving the level of government regulation, which allows not only to organize but also to maintain constant and effective control over the activities of the transport sector. As for Ukraine, in recent years the situation in almost all transport sectors has deteriorated in all sectors of transport, except air transport. This confirms the relevance of the study of state regulation in the field of transport, which will find ways to address the situation.

The main bodies that carry out state regulation in the field of motor transport are identified, for this purpose a three-level hierarchical structure is proposed, which is formed at the national, regional and local levels. The main tasks of the Ministry of Infrastructure of Ukraine are defined and its role in the activity of the transport branch is reflected. The spheres of influence of each of the regulatory bodies on different types of transport are considered.

In addition to systematizing information on the institutional regulation of the transport sector, an analysis of the regulatory framework in this area. The main problematic aspects of the state regulation of the transport sphere are identified and for the first time measures are proposed that will allow solving these issues in accordance with the current state of the industry.

Ключові слова: держаВне регулюВання, транспорт, інфраструктура.

Key words: state regulation, transport, infrastructure.

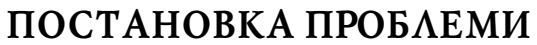

Одним із стратегічних напрямів розвитку держави $\epsilon$ ефрективне регулювання у сфері транспорту, транспортною системою таїї інфраструктурою, тобто діяльністю всіх видів транспорту, які виступають основними чинниками створення сприятливих умов для повноцінного функціонування економіки. На сьогодні рівень ефективності державного регулювання та діяльності транспортного сектору не повною мірою відповідає вимогам ринкової економіки та тенденціями економічного розвитку. Поєднуючи державне регулювання із фрункціональною діяльністю транспорту, виникає ряд проблем, які стають стримуючими чинниками на шляху до вдосконалення ринкових відносин, і перешкоджає фрормуванню сучасного ринкового середовища. Особливо гостро стоїть питання взаємодії держави та приватного сектору транспортного комплексу.

За останні 20 років більшість країн світу намагаються удосконалювати свою транспортну інфраструктуру шляхом удосконалення рівня державного регулювання, яке дозволяє не тільки організувати, але й вести постійний і дієвий контроль за діяльністю транспортного сектору. Що стосується України, то останніми роками практично у всьому транспортному комплексі відчувається погіршення ситуації у всіх галузях транспорту, окрім авіатранспорту. Це підтверджує актуальність дослідження державного регулювання у сфері транспорту, що дозволить знайти напрями вирішення ситуації, що склалася.

\section{АНА $\Lambda$ I3 ОСТАНHIX АОС $А$ АЖЕНЬ І ПУБАІКАЦІЙ}

На сьогодні, якщо основні організаційні моменти державного регулювання досліджуються науковцями на високому рівні, то питання державного регулювання у сорері транспорту досліджується недостатньо. Питання розвитку транспортної сорери досліджували автори: Гурнак В.М. [1], Ковалев Д.І. [2], Максимова С.Ю. [3], Рудченко О.Ю., Поліщук О.М. [4], Богомолова Н.І. [6] та інші. 


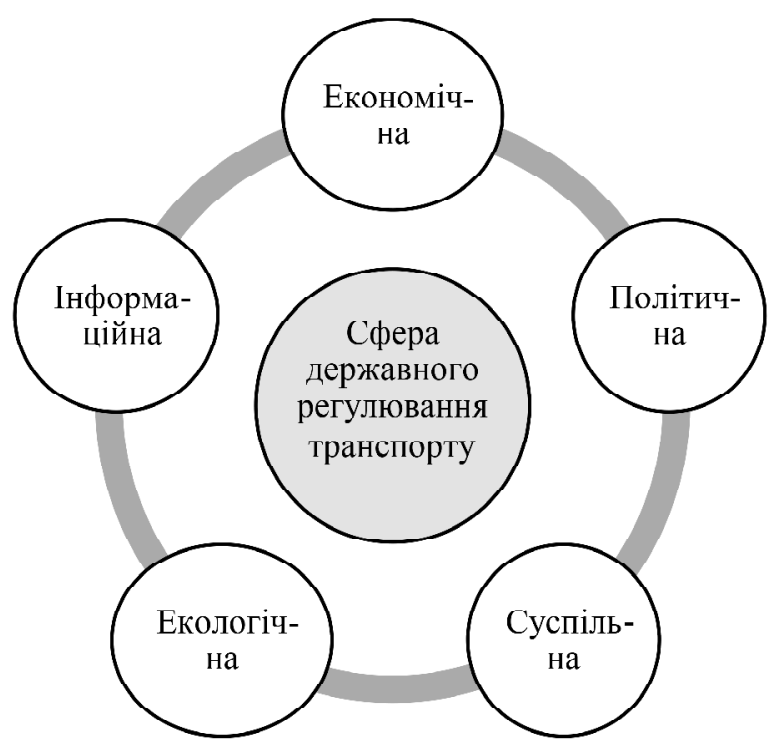

Рис.1. Види сфер державного регулювання транспортної галузі

\section{META CTATTI}

Метою статті $€$ виявлення ключових проблем у транспортній сорері та розроблення напрямів щодо їх вирішення шляхом оцінювання та систематизації механізмів державного регулювання.

\section{ВИК ААА ОСНОВНОГО МАТЕРІААУ}

Перш ніж досліджувати питання державного регулювання у сорері транспорту, слід визначити поле державного регулювання, його суть та функції. Процеси державного регулювання $є$ широко досліджуваними у науковій літературі [1-3]. Зокрема, частина авторів розглядає державне регулювання як системне поєднання інструментів, методів, форм та важелів, які використовуються державою відповідно до чинного законодавства та інформаційного забезпечення на мікро- та макрорівнях [1].

Державне регулювання є складовою системи управління, на яку впливають внутрішні та зовнішні чинники, від яких залежить результативність державного регулювання. Процес державного регулювання формує механізм, до складу якого входять цілі, методи впливу, інструменти, що використовуються для здійснення регулювання, ресурси управління, що дозволяють побудувати організаційний та соціальний потенціал, спрямований на досягнення основної мети - покращення транспортної сорери. Регулювання здійснюється державною владою в особі певних інститутів.

В Україні, як і в багатьох розвинених країнах світу, транспорт $\epsilon$ однією із ключових галузей народного господарства, яка фрормує виробничу та соціальну структуру. Розвиток транспорту визначає рівень конкурентоспроможності держави та дозволяє зміцнити фрінансову стійкість економічних суб'єктів та держави загалом. У зв'язку із цим державне регулювання підтримки та розвитку транспорту є одним із пріоритетних на шляху до побудови стратегічних напрямів розвитку країни [2].

Питання транспортної сфери, інфрраструктури транспорту та системи транспорту розглядалося багатьма вітчизняними вченими. Зокрема, в обіг введене по- няття "транспортної інфрраструктури" як сукупності сорер діяльності транспортних компаній та регулюючих компаній, основна мета яких - переміщувати товари від виробника до споживача, та задовільняти потреби населення у вільному пересуванні [3]. Транспортна інфраструктура поєднує процеси виробництва, розподілу, обміну та споживання.

Отже, можна дійти висновку про те, що транспортну сферу формують транспортні підприємства та органи, що регулюють їх діяльність. Розглянемо більш детально складові фрінансової сфери.

Основною метою діяльності підприємств транспортної галузі $€$ прискорення оборотності матеріальних, фрінансових, інформаційних, трудових потоків у межах просторової структури із врахуванням, що всі елементи структури пов'язуються на всіх рівнях фрункціонування. Транспортні підприємства виступають основними вузлами, що дозволяють об'єднати всі ці потоки. У свою чергу державне регулювання транспортом визначається як планомірна та безперервна діяльність органів державної влади, яка спрямовується на створення та забезпечення своєчасності надання транспортних послуг та їх якості. Державне регулювання транспорту $є$ обов'язковою передумовою ефективного використання потенціалу транспорту з метою стабілізації умов здійснення економічної діяльності. Державне регулювання транспортної галузі здійснюється у різних сферах: політичній, економічній, соціальній, інформаційній, екологічній [4] (рис. 1).

Розглянемо більш детально, як впливає кожна із зазначених сорер на транспортну галузь.

1. Політична сфрера має дуже важливий вплив на державне регулювання. В основному вона зумовлює формування нормативно-правової бази у сорері транспорту, а також формування стратегії розвитку транспортної галузі, здійснення її фрінансування тощо.

2. Економічна сорера $є$ рушійною силою, яка дозволяє транспортній галузі розвиватися шляхом фрінансування, а також розроблення цільових програм та розвитку міжнародного, державного та державно-приватного партнерства. Необхідно зазначити, що на економічну сореру регулювання додатково впливають інші чинники, які можна класифікувати як внутрішній та зовнішній. Внутрішніми чинниками є добробут населення, сплата ним податків, а також громадська ініціатива з розвитку транспортної системи. Зовнішніми чинниками $€$ міжнародні відносини та вплив інших країн на фінансування транспортної галузі [5].

3. Інформаційна сорера дозволяє впроваджувати сучасні технології в управління транспортною сферою. На сьогодні використання таких технологій дозволяє швидше розвиватися усьому транспортному сектору, а населенню отримувати зручні та доступні послуги.

4. Екологічна сорера зумовлюється дотриманням безпеки дорожнього руху, а також застосуванням екологічних програм, правил та заходів щодо безпеки та якості транспорту та транспортної інфрраструктури [4].

Загалом можна стверджувати, що державне регулювання у сорері транспорту - це система взаємодії між суб'єктами управління, яка містить економічну, мотивацію, організаційну та політичну складові. Діяльність органів влади організовується на принципах та завдан- 
нях із врахуванням функцій планування, організування, стимулювання розвитку та контролю, що дозволяє здійснювати цільовий вплив на об'єкти управління з метою розвитку сфери транспорту [4].

Державне регулювання полягає у грамотному підборі інструментів та методів управління, які дозволяють підвищити ефективність діяльності об'єктів транспортної інфрраструктури держави.

Державне регулювання відбувається шляхом здійснення функцій органами регулювання. Основними функціями державного регулювання транспортної системи $€$ надання послуг господарюючим суб'єктам та створення сприятливих умов щодо розвитку транспортної галузі. Для того щоб реалізувати функцію управління, використовують різні методи державного регулювання. Розглянемо основні методи державного регулювання, які використовуються у транспортній сорері:

1) механізми встановлення взаємних відносин між об'єктами та суб'єктами державного регулювання транспортної сорери;

2) реалізація компетенцій суб'єктів державного регулювання відповідно до їх повноважень;

3) практична реалізація державної влади шляхом впливу на об'єкти державного управління відповідно до інтересів та цілей розвитку держави;

4) реалізація цілей та функцій державного управління [6].

У залежності від здійснення певних функцій вибирається той чи інший метод державного управління. Серед методів державного регулювання транспортної сфрерою виділяють:

- прямі методи, до яких відноситься використання державних інвестицій, використання закордонних інвестицій, застосування податкових пільг, створення фондів фрінансування та підтримки;

- непрямі методи, до яких відноситься: розроблення програм економічного зростання, створення умов для фрормування заохочувальної цінової політики, використання системи державних замовлень та закупівель, визначення норм охорони навколишнього середовища, постанова правил та інструкцій, становлення податків та штрафрних станцій, нормативів, стандартів тощо [4; 5].

Державні органи за допомогою різних інструментів посилюють свою роль регуляторів ринкових взаємовідносин та зберігають відповідальність за створення безпечних умов для здійснення транспортного процеcy.

Система державного регулювання у сфері транспорту має трирівневу ієрархічну структуру (рис. 2).

Необхідно зазначити, що державне регулювання здійснюється на трьох рівнях: місцевому, регіональному та національному рівні. Основними органами державного регулювання є Верховна Рада України, Кабінет Міністрів України, Міністерство інфрраструктури України.

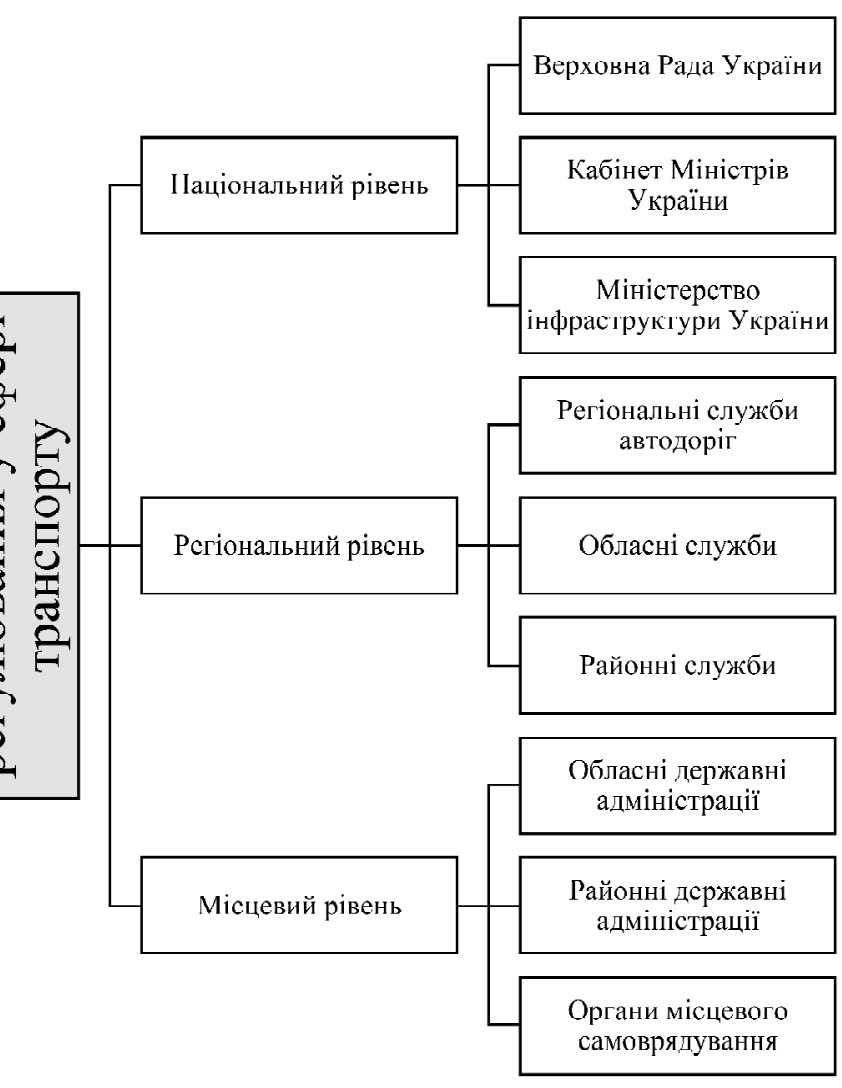

Рис. 2. Ієрархічна структура державного регулювання у сфері транспорту

Джерело: систематизовано та згруповано авторами.

На місцевих рівнях державне регулювання здійснюють обласні державні адміністрації, районні державні адміністрації та органи місцевого самоврядування.

Розглянемо роль кожного із державних регуляторів сорери транспорту більш детально. Головну роль у реалізації державної політики у сфрері транспортування відіграє Міністерство Інфраструктури України, діяльність якого грунтується на:

- демократичних принципах, фрормуванні прозорих відносин із громадськістю, а також створенні стратегічних напрямів діяльності, яка спрямовується на впровадження європейського законодавства у сорері сталого розвитку транспортної сорери України до вітчизняного з метою забезпечення високого рівня якості та міжнародної кооперації;

- активізації процесів децентралізації функцій Міністерства та делегування повноважень на місця здійснення діяльності;

- пришвидшенні демонополізації у сфрері транспортних послуг;

- формуванні нормативно-правової бази для здійснення діяльності транспортних компаній, що фрінансуються з бюджету;

- залученні громадського сектору до вирішення питань розвитку транспортної сорери.

Основними завданнями Міністерства інфрраструктури України є:

- реалізація державної політики у сорері транспорту та дорожнього господарства, що спрямовується на 


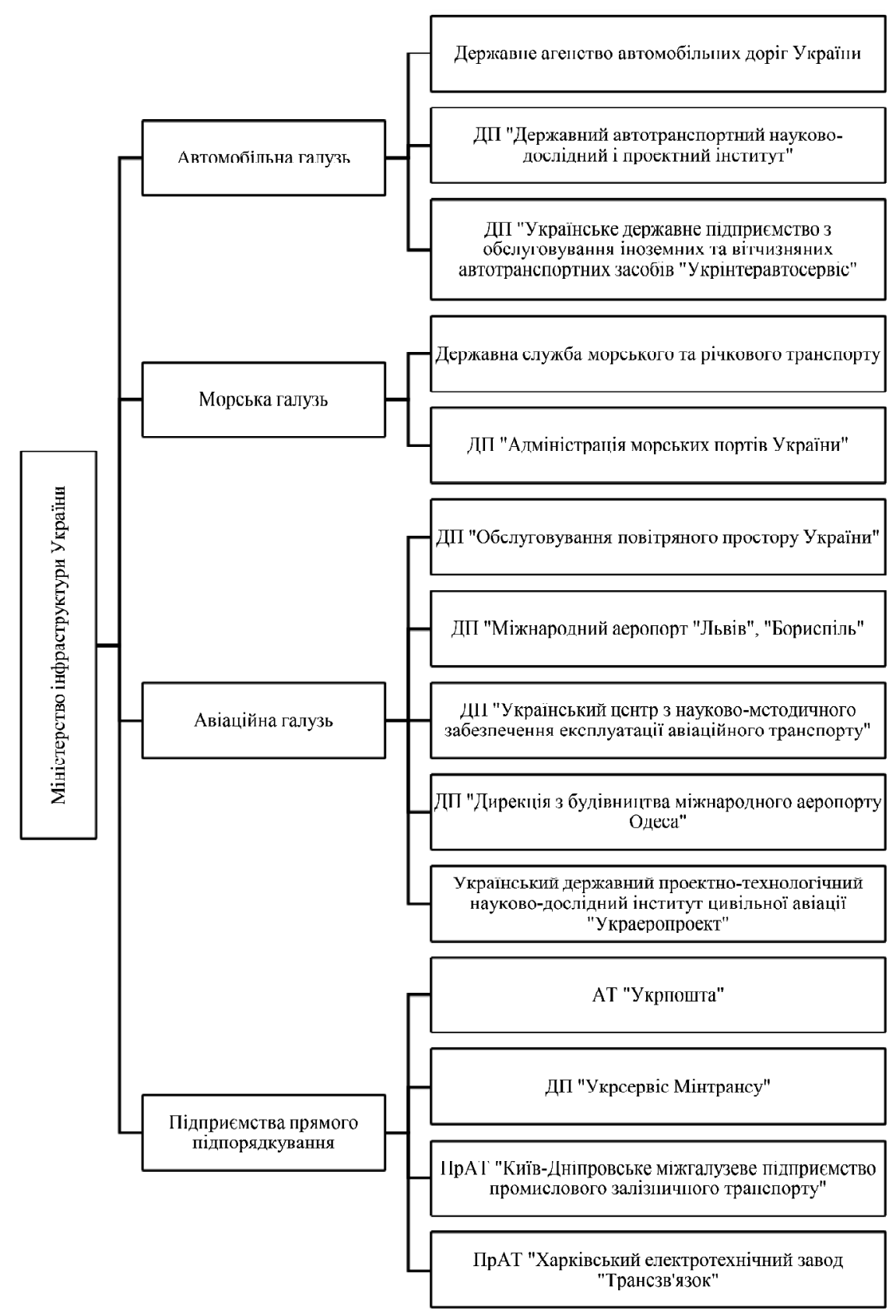

Рис. 3. Структура державного регулювання Міністерства інфраструктури України у сфері транспорту

Джерело: згруповано авторами.

створення безпечних умов надання транспортних послуг;

- забезпечення регулярних перевезень та утримання транспортної інфраструктури загального користування, регіонального та місцевого значення для забезпечення вільного пересування населення та вантажу;

- формування єдиного економічного простору, а також транспортної та екологічної безпеки;

- розроблення та впровадження національних, регіональних та місцевих планів щодо розвитку транспортної сфрери, а також програм розвитку дорожнього господарства, використання повітряного простору України, розвитку туризму, діяльності курортів, надання послуг поштового зв'язку;
- впровадження заходів щодо покращення рівня безпеки перевезення пасажирів та вантажів відповідно до наданих компетенцій;

- розвиток стандартизації у сорері будівництва, реструктуризації та утримання автомобільних доріг загального користування різного рівня значення;

- реалізація повноважень єдиної фрінансової та бюджетної політики у сфері транспорту.

Міністерство інфрраструктури України у процесі здійснення регуляторних функцій повинно виконувати наступні дії:

- забезпечувати демократичну та інноваційну політику, направлену на удосконалення державного регулювання транспортної сфери, визначаючи ії пріоритетні напрями розвитку за всіма видами транспорту;

- розробляти та затверджувати нормативні та законодавчі акти, а також будувати архітектуру законодавчого та нормативного регулювання для забезпечення ефективності регулювання транспортної сорери;

- впроваджувати затверджені плани розвитку транспортної сорери та розробляти стратегічні плани та програми, забезпечуючи ефективну комунікаційну політику на всіх рівнях державного регулювання;

- реалізувати принципи державного та приватного партнерства в області транспортної інфрраструктури та модернізувати механізми його здійснення, що максимально наближені до поточних умов сорери транспортування;

- забезпечити передумови для ефективних комунікацій зацікавлених сторін у розвитку транспортної сорери.

Міністерство інфрраструктури України здійснює регулювання автомобільної, морської, авіаційної галузі та підприємств прямого підпорядкування [7] (рис. 3).

Основними регуляторами автомобільної галузі $\epsilon$ регіональні служби автомобільних доріг, обласні служби автомобільних доріг, районні служби автомобільних доріг.

Що стосується державного регулювання автомобільної галузі, то основним органом $€$ Державне Агентство автомобільних доріг України, Державне підприємство "Державний автотранспортний науково-дослідний і проєктний інститут", Державне підприємство "Українське державне підприємство по обслуговуванню іноземних та вітчизняних автотранспортних засобів "УкрІнтерАвтоСервіс". 
Таблиця 1. Законодавча нормативно-правова база з питань державного регулювання у транспортній сфері

\begin{tabular}{|c|c|c|}
\hline $\begin{array}{c}\text { Сфера } \\
\text { застосування }\end{array}$ & Законодавчий акт & Номер та дата прийняття \\
\hline \multirow{3}{*}{$\begin{array}{l}\text { Загальні } \\
\text { положення }\end{array}$} & Конституція України & № 254к/96-ВР від 28.06.1996 р. \\
\hline & Про Кабінет Міністрів України & № 794-VII від 27.02.2014 p. \\
\hline & Про центральні органи виконавчої влади & № 3166-VI від 17.03.2011 p. \\
\hline \multirow[t]{3}{*}{ Галузеві } & Про автомобільні дороги & № 2862-IV від 08.09.2005 p. \\
\hline & Про транспорт & № 232/94-ВР від 10.11.1994 р. \\
\hline & Про дорожній рух & № 3353-ХІІ від 30.06.1993 p. \\
\hline \multirow{4}{*}{$\begin{array}{l}\text { Техніко- } \\
\text { технологічна } \\
\text { модернізація }\end{array}$} & $\begin{array}{l}\text { Про джерела фінансування дорожнього } \\
\text { господарства України }\end{array}$ & № 1562-ХІІ від 18.09.1991 р. \\
\hline & $\begin{array}{l}\text { Про ратифікацію Фінансової угоди між } \\
\text { Україною та Європейським інвестиційним } \\
\text { банком }\end{array}$ & № 4042-VI від 16.11.2011 p. \\
\hline & $\begin{array}{l}\text { Про ратифікацію Кредитної угоди між } \\
\text { Україною та Свропейським банком } \\
\text { реконструкції та розвитку }\end{array}$ & № 928-V від 13.04 .2007 p. \\
\hline & $\begin{array}{l}\text { Про реконструкцію та експлуатацію } \\
\text { на платній основі автомобільної дороги } \\
\text { Київ - Одеса }\end{array}$ & № 855-IV від 22.05.2003 p. \\
\hline Перевезення & Про перевезення небезпечних вантажів & № 1644-III від 06.04.2000 p. \\
\hline \multirow[t]{3}{*}{ Фінансування } & Бюджетний кодекс України & № 2456-VI від 08.07.2010 p. \\
\hline & $\begin{array}{l}\text { Про державний бюджет України на } \\
\text { відповідний рік }\end{array}$ & - \\
\hline & $\begin{array}{l}\text { Про джерела фінансування дорожнього } \\
\text { господарства України }\end{array}$ & № 1562-ХІІ від 18.09.1991 p. \\
\hline Стратегічні цілі & $\begin{array}{l}\text { Про схвалення Національної транспортної } \\
\text { стратегії України на період до } 2030 \text { року }\end{array}$ & № 430-р від 30.05.2018 p. \\
\hline
\end{tabular}

Джерело: згруповано автором.

Що стосується морського транспорту, то основними органами державного регулювання $є$ Державна служба морського та річкового транспорту та Державне підприємство "Адміністрація морських портів України".

У авіаційній галузі основними регулятивними органами є: Державне підприємство обслуговування повітряного руху України, Державне підприємство "Міжнародний аеропорт "Львів ім. Данила Галицького", Державне підприємство "Міжнародний аеропорт Бориспіль", Державне підприємство "Український центр з науково-методичного забезпечення, експлуатації авіаційної техніки", Державне підприємство "Дирекція з будівництва міжнародного аеропорту "Одеса", Український державний проєктно-технологічний науково-дослідний інститут цивільної авіації "УкрАеропроєкт".

Центральним органом виконавчої ради виступає Державне агентство автомобільних доріг України "Укравтодор"[8]. Компанія підпорядковуються Міністерству інфраструктури України. Основною функцією Укравтодору $є$ реалізація державної політики в області державного господарства та управління автодорогами на всіх рівнях шляхом забезпечення управління автомобільними дорогами загального, загальнонаціонального та місцевого користування. Укравтодор активізує та підтримує розвиток транспортної сорери, забезпечує високий рівень безпеки дорожнього руху, здійснює створення та підтримування стандартів якості надання послуг з перевезення пасажирів та вантажів автомобільним транспортом. До функцій цього органу також входить впровадження інноваційних проєктів, підвищення рівня експлуатаційного стану автодорожніх доріг, сприяння розвитку транспортної інфрраструктури на принципах інклюзії, тобто збільшуючи рівень покриття доріг у сільській місцевості, а також забезпечуючи рівні права щодо безперешкодного пересування міським та сільським населенням, розвиток конкурентних переваг вітчизняних автомобільних доріг з метою активізації туристичного сектору у різних напрямах. Окрім цього, Укравтодор здійснює свою діяльність у складі ПрАТ "Автомобільні дороги України", яка вважаються монополістом на вітчизняному ринку будівництва доріг. Транспортна компанія виступає однією із важливих компаній, що впливають на розвиток економіки, вона займається забезпеченням сталого розвитку та ефективності державного управління.

Отже, державне регулювання здійснюється у різних copepax i $є$ особливо потрібним для реалізації публічних інтересів. Так, відповідно до Закону України "Про транспорт" основною метою державного регулювання транспортної сорери є своєчасне, повне та якісне задоволення потреб населення та економіки у перевезеннях та забезпечення потреб оборони держави, захисту прав споживачів.

Окрім зазначеного закону, транспортні відносини регулюються й іншими нормативними та законодавчими документами. Зокрема, основою нормативно-правового забезпечення у сорері транспортної інфрраструктури є Закон України "Про автомобільні дороги", "Про транспорт", "Про дорожній рух" тощо. Розглянемо більш детально Закони України, які діють у сфері транспортування та регулюють її.

Органи виконавчої влади та органи місцевого самоврядування забезпечують реалізацію державної політики у сорері транспорту та розробляють місцеві та регіональні програми з його розвитку, встановлюючи тарифи за проїзд, інфрормуючи населення про прийняття рішень і здійснюючи контроль за процесом перевезення.

Окрім законодавчих актів, існують і підзаконні нормативно-правові акти, до яких відносяться постанови Кабінету Міністрів із розвитку та регулювання транспор- 
тної сорери. Ці постанови приймаються щороку з питань здійснення реконструкції об'єктів транспортної сорери, використання коштів, затвердження проєктів робіт та робочих проєктів.

Зудосконаленням нормативно-правової бази з'являється можливість вирішення багатьох проблем транспортної сорери, що у результаті стає пріоритетом державного регулювання у сфері транспорту. Однак, щоб охопити процес удосконалення комплексно, необхідно впровадити ряд поправок на всіх рівнях транспортного регулювання. Зокрема, правове забезпечення економічних процесів, що відбуваються у державі, $є$ похідними від конституційного правопорядку, а тому для того, щоб удосконалити фрінансову частину регулювання, слід удосконалювати законодавчу базу на всіх рівнях регулювання, починаючи від Конституції і Кодексів [9].

Насамперед основні напрями удосконалення державного регулювання повинні здійснюватися в бік фрормування партнерських взаємовідносин між державою та приватним транспортним сектором [10]. Враховуючи те, що суб'єкти господарювання, які надають транспортні послуги, несуть публічні зобов'язання, необхідно удосконалювати модель партнерства між приватними та державними інтересами учасників транспортних відносин. Основним правовим підгрунтям для цього $є$ Господарський кодекс України, Цивільний кодекс України, а також зазначене у таблиці 1 транспортне законодавство, яке регулює правила перевезення пасажирів та вантажів.

Важливим напрямом розвитку правового регулювання стало прийняття Верховною Радою України в 2020 році Закону України "Про внутрішній водний транспорт". Цей закон сприяє створенню річкового шляху від Чорного до Балтійського моря у рамках міжнародного проєкту між Польщею, Білоруссю та Україною, а також дозволяє оновити стратегію розвитку морських портів до 2038 року.

У сорері залізничного транспорту започатковано експериментальний проєкт, який дозволяє допускати приватні локомотиви на залізничні колії загального користування. У рамках цього проєкту укладено перший договір про допуск приватних локомотивів на деякі із залізничних дільниць ТОВ "Українська локомотивна будівельна компанія" [11]. Першим кроком до створення конкурентного ринку залізничних перевезень $€$ забезпечення рівноправного доступу приватних організацій до залізничної інфраструктури та впровадження нової моделі співпраці на ринку. Це потребує удосконалення нормативного законодавства у сфері залізничного транспортування.

На сьогодні залишається досить гострою проблема залучення інвестицій у транспортну сфреру, тому важливим напрямом розвитку державного регулювання $\epsilon$ створення та реалізація проєктів, які орієнтуються на державно-приватне партнерство. Зокрема, у 2020 році укладені перші договори, відповідно до яких сорормована велика кількість масштабних проєктів у галузі інфраструктури та транспорту. Ці інвестиційні проєкти охоплюють практично всі галузі транспорту, а особливо морський та залізничний [12].

3 метою покращення інформаційного забезпечення та поширення систем диджиталізації, у транспортну сфреру впроваджується поняття електронних товарнотранспортних накладних для здійснення міжнародних перевезень вантажів автомобільним транспортом у рамках експериментального проєкту [13]. Також важливим $€$ розвиток транспортного коридору Європа-КавказАзія у галузі залізничного сполучення та інфраструктури за програмою міжнародного співробітництва TРАСЕКА. Сюди відноситься розвиток мультимодальних перевезень та створення цифрових коридорів, які полегшують здійснення міжнародних транспортних перевезень [14].

Окрім того, важливою складовою розвитку транспортної системи стає залучення у великих масштабах нових видів транспорту - дронів (квадрокоптерів), які будуть використовуватися для перевезення вантажів, а також для доставки продуктів населенню та можуть застосовуватися у інших логістичних операціях. Однак на сьогодні зазначене питання взагалі не має нормативноправового регулювання, а тому потребує належної уваги зі сторони регуляторів [15].

\section{ВИСНОВКИ}

На сьогодні державне регулювання транспортного сектору має високо-організовану інституційну структуру, яка створює передумови для розвитку транспортної галузі, здійснює її організацію та контролює на всіх рівнях державного управління. Попри достатньо складну систему державного регулювання, на сьогодні у транспортній галузі виникає чимало питань, які стосуються фрінансування, інвестицій та розвитку. По факту ж транспортна інфрраструктура щороку погіршується і вже протягом багатьох років знаходиться у кризовому стані. Для того щоб подолати проблеми кризового стану у транспортній сорері, необхідно підвищити дієвість державного регулювання шляхом фрормування сприятливого інституційного середовища, впровадження поправок до діючих законодавчих актів та розроблення нових. Підвищивши якість управління у сорері транспортування, державі вдасться залучити більше інвестицій, що дозволить галузі розвиватися стрімкішими темпами. Залучення інвестицій і подальший розвиток транспортної галузі повинні відбуватися на основі державно-приватного партнерства. Рекомендується розробити та імплементувати такі умови для приватного транспортного та інших секторів економіки, які стануть економічно вигідними для здійснення інвестицій. Це в подальшому дозволить вирішити проблемні питання у сфрері постачання продукції або перевезення пасажирів і в результаті зумовить розвиток транспортної галузі в країні.

\section{Література:}

1. Гурнак В.М. Транспортно-дорожній комплекс України на сучасному етапі (Стан. Проблеми. Перспективи.) Залізн. трансп. України. 2006. № 4. С. 14-16.

2. Ковалев Д.И. Проблемы Единой транспортной системы Украины. Вісник економіки транспорту і промисловості: зб. наук. пр. Спец. випуск. Х.: УкрДАЗТ, 2006. № 14. С. $21-22$.

3. Максимова С.Ю. Инновационные технологии в управлении развитием транспортно-логистической инфрраструктуры региона. Инновации в экономике, управ- 
лении и образовании: монография. Ставрополь: СИЭУ ФПГТУ, 2009. С. 41-42.

4. Рудченко О.Ю., Поліщук О.М. Механізм державного регулювання транспортної інфраструктури мегаполісів. Університетські наукові записки. 2017. № 6. С. $93-100$.

5. Дейнека А.Г. Регулирование интеграционных процессов на транспорте: инвестиционный аспект. Вісник економіки транспорту і промисловості: Зб. наук. праць. Харків: Укр ДАЗТ. 2005. № 11. С. 157-160.

6. Богомолова Н.І. Особливості державного регулювання розвитку транспорту мегаполісу. Збірний наукових праць ДЕТУТ. Серія "Економічні науки". 2015. № 33. С. $213-218$.

7. Офріційний сайт Міністерства інфраструктури України. URL: http://mtu.gov.ua/documents/358.html

8. Державне агентство автомобільних доріг України Укравтодор. URL: Режим доступу: https:// ukravtodor.gov.ua/

9. Проєкт Закону України "Про внесення змін до Господарського кодексу України (щодо узгодження 3 положеннями Цивільного кодексу України та деяких інших законодавчих актів) від 29 вересня 2020 р. Офріційний веб-портал Верховної Ради України. URL: http: / /w1.c1.rada.gov.ua/pls/zweb2/webproc4_1?pf3511

10. Полякова О. Світовий досвід формування транспортно-логістичних кластерів. Збірник наукових праць Державного економіко технологічного університету транспорту. Серія: Економіка і управління. 2014. № 28. С. $14-21$.

11. УЗуклала перший договір у рамках експерименту із допуску приватних локомотивів на залізницю. 2020. 17 грудня. Офріційний веб-портал Міністерства інфраструктури України. URL: https://mtu.gov.ua/news/ 32474.html

12. $40 \%$ пріоритетних для держави інвестпроєктів складають проєкти у галузі інфрраструктури та транспорту. 2020. 20 листопада. Офріційний веб-портал Міністерства інфрраструктури України. URL: https://mtu.gov.ua/ news/32396.html

13. Порядок реалізації експериментального проєкту щодо забезпечення впровадження замовлення бланків дозволів на поїздку по територіях іноземних держав при виконанні перевезень вантажів автомобільним транспортом у міжнародному сполученні в електронній формі через Транспортний портал електронних послуг: постанова Кабінету Міністрів України від 3 червня. 2020. № 473. Офріційний вісник України. 2020. № 49. Ст. 1535.

14. Січкар Д. Транспортна галузь у 2020 році. Вебпортал Європейської Бізнес Асоціації. 2020. 22 грудня. URL: https://eba.com.ua/transportna-galuz-u-2020rotsi/

15. Drones in the Transport System: Acceptability and Integration. International Transport Forum. URL: https:/ /www.itf-oecd.org/drones-transport-system-acceptability-integration

References:

1. Hurnak, V.M. (2006), "Transport and road complex of Ukraine at the present stage. (Status. Problems. Perspectives.)", Zalizn. transp. Ukrainy, vol. 4. pp. 14-16.
2. Kovalev, D.Y. (2006), "Problems of the Unified Transport System of Ukraine", Visnyk ekonomiky transportu i promyslovosti, vol. 14, pp. 21-22.

3. Maksymova, S. Yu. (2009), "Innovative technologies in the management of the development of the transport and logistics infrastructure of the region", Ynnovatsyy $v$ ekonomyke, upravlenyy y obrazovanyy [Innovations in economics, management and education], SYEU FPHTU, Stavropol', Russia, pp. 41-42.

4. Rudchenko, O.Yu. and Polischuk, O.M. (2017), "The mechanism of state regulation of transport infrastructure of megacities", Universytets'ki naukovi zapysky, vol. 6, pp. 93-100.

5. Deyneka, A.H. (2005), "Regulation of integration processes in transport: investment aspect", Visnyk ekonomiky transportu i promyslovosti, vol. 11, pp. 157-160.

6. Bohomolova, N.I. (2015), "Features of state regulation of transport development of the metropolis", Zbirnyj naukovykh prats' DETUT. Seriia "Ekonomichni nauky", vol. 33, pp. 213-218.

7. Ministry of Infrastructure of Ukraine (2015), Order "On measures for the development of road transport and road management for the period up to 2020", available at: http:/ /mtu.gov.ua/documents/358.html (Accessed 25 July 2021).

8. Ukravtodor (2021), available at: https://ukravtodor.gov.ua/ (Accessed 25 July 2021).

9. Verkhovna Rada of Ukraine (2020), Draft Law "On amendments to the Commercial Code of Ukraine (regarding harmonization with the provisions of the Civil Code of Ukraine and some other legislative acts)", available at: http://w1.c1.rada.gov.ua/pls/zweb2/webproc4_1?pf3511 (Accessed 25 July 2021).

10. Poliakova, O. (2014), "World experience in the formation of transport and logistics clusters", Zbirnyk naukovykh prats' Derzhavnoho ekonomiko tekhnolohichnoho universytetu transportu. Seriia: Ekonomika i upravlinnia, vol. 28, pp. 14-21.

11. Ministry of Infrastructure of Ukraine (2020), "UZ signed the first contract in the framework of an experiment on the admission of private locomotives to the railway", available at: https://mtu.gov.ua/news/32474.html (Accessed 25 July 2021).

12. Ministry of Infrastructure of Ukraine (2020), " $40 \%$ of priority investment projects for the state are infrastructure and transport projects", available at: https:// mtu.gov.ua/news/32396.html (Accessed 25 July 2021).

13. Cabinet of Ministers of Ukraine (2020), Resolution "The order of realization of the experimental project on maintenance of introduction of the order of forms of permissions for travel on territories of foreign states at performance of transportations of freights by motor transport in the international communication in the electronic form through the Transport portal of electronic services", Ofitsijnyj visnyk Ukrainy, vol. 49.

14. Sichkar, D. (2020), "Transport industry in 2020", available at: https://eba.com.ua/transportna-galuz-u2020-rotsi / (Accessed 25 July 2021).

15. International Transport Forum (2021), "Drones in the Transport System: Acceptability and Integration", available at: https://www.itf-oecd.org/drones-transport-systemacceptability-integration (Accessed 25 July 2021). Стаття надійшла до редакиї 05.08.2021 p. 